\title{
MITOS DAN HIPERREALITAS KOMUNIKASI POLITIK (Studi Iklan Pemilu Jusuf Kalla-Wiranto Versi Humble dan Mampu)
}

\author{
Anang Masduki \\ Ilmu Komunikasi Universitas Ahmad Dahlan Yogyakarta \\ anang_masduki@yahoo.com
}

\begin{abstract}
One of the main elements in a modern democratic politics is widespread political advertisement. In the 2009 election in Indonesia, one of the main partner, namely Jusuf Kalla and Wiranto also do advertising, especially on television. This is done to boost the popularity and elektabilitasnya to win the election. And in these ads are myths and hyperreality. This study was conducted to uncover the myths and hyperreality that exist in the ad with the title "humble" and "mampu" belonging to the couple. The method used is semiotic theories of Roland Barthes. with a two-stage approach popularized by Roland Barthes, connotations and meanings denotation, meaning the disclosure of the symbols in advertising will be more striking. From the analysis found that the phrase statesman and populist become the focus of myths and hyperreality conducted by Jusuf Kalla and Wiranto in its advertising.
\end{abstract}

\begin{abstract}
Abstrak
Salah satu elemen politik dalam demokrasi modern adalah merebaknya iklan politik. Dalam pemilu 2009 di Indonesia salah satu pasangan yaitu Jusuf Kalla dan Wiranto juga melakukan iklan khususnya di televisi. Hal ini dilakukan untuk mendongkrak popularitas dan elektabilitasnya demi memenangkan pemilu. Di dalam iklan tersebut terdapat mitos dan hiperrealitas. Penelitian ini dilakukan untuk mengungkap mitos dan hiperrealitas yang ada dalam iklan dengan judul "humble" dan "mampu" milik pasangan tersebut. Adapun metode yang digunakan adalah teori semiotika Roland Barthes. dengan pendekatan dua tahap yang dipopulerkan oleh Roland Barthes, makna konotasi dan makna denotasi, pengungkapan makna simbol-simbol dalam iklan akan semakin mencolok. Dari analisis didapat bahwa frase negarawan dan merakyat menjadi fokus mitos dan hiperrealitas yang dilakukan oleh Jusuf Kalla dan Wiranto dalam iklannya.
\end{abstract}

Keywords: Myth, Hyperreality, Political Advertising 


\section{PENDAHULUAN}

Politik senantiasa menarik untuk diperbincangkan. Dari rakyat elit sampai rakyat jelata di warung-warung, di pasar dan di pos ronda mulai membicarakan politik. Hal ini tidak terlepas dari lahirnya zaman reformasi. Dimana kebebasan berpendapat mendapat perlindungan hukum. Begitu juga dengan para intelektualis banyak pula yang mengkajinya dalam seminar maupun workshop.

Tidak terkecuali dengan komunikasi politik, pergeseran komunikasi politik di zaman reformasi juga mendapat momentumnya. Dulu tidak pernah kita menyaksikan iklan politik atau kampanye di televisi. Sekarang jika menjelang pemilihan umum maupun pemilihan kepala daerah kita disuguhi berbagai macam iklan bakal calon pemimpin.

Dari iklan tersebut masyarakat bisa menilai positif dan juga negatif. Positif, ketika masyarakat bisa mengenal sosok yang akan memimpinnya. Begitu juga sang kandidat bisa mensosialisasikan agenda kedepan jika terpilih. Negatifnya, banyak iklan yang dinilai hanya manis dipermukaan, minim substansi dan cenderung menjual retorika belaka. Maka dikenal istilah hipperrealitas dan mitos khususnya dalam iklan politik.

Hiperrealitas dan mitos dalam iklan muncul seiring dengan rendahnya intensitas kandidat dalam sosialisasi langsung atau terjun ke masyarakat sehingga tidak dikenal. Maka cara instan adalah membuat iklan untuk mengenalkan diri. Akan tetapi menjadi permasalahan jika sunstansi iklan cenderung memuat sesuatu yang dilebihkan dan diberi kesan positif secara singkat dan padat. Hal ini dapat dimaklumi karena memang iklan dibatasi oleh durasi. Namun bukan berarti sang kandidat bebas menjual jargon maupun program seenaknya. Tentu harus tetap mematuhi dan menjunjung tinggi etika dan norma serta budaya bangsa Indonesia.

Salahsatu elit politik yang memeriahkan kontestasi pemilu tahun 2009 di Indonesia adalah pasangan Jusuf Kalla dan Wiranto. Jusuf Kalla merupakan ketua umum partai
Golkar. Adapun Wiranto adalah ketua umum partai Hanura. Keduanya adalah politisi Indonesia yang sudah tidak asing lagi dimata publik. Jusuf Kalla saat itu masih menjabat wakil presiden, atau sebagai pendamping SBY. Namun keduanya pecah kongsi. Banyak politisi maupun pengamat melihat sebab pecahnya kongsi tersebut karena peran JK yang amat dominan, sedangkan SBY tidak menyukai adanya matahari kembar. Adapun Wiranto adalah pensiunan jendral angkatan darat, mantan panglima TNI dan juga mantan Menkopolhukam. Dulu Wiranto juga merupakan kader Golkar. Bahkan dalam pemilu tahun 2004 Wiranto memenangi konfensi partai Golkar sehingga maju menjadi calon presiden.

Keduanya jauh-jauh hari sebelum memasuki masa kampanye telah mempersiapkan diri untuk maju menjadi calon presiden, hal ini terlihat dari iklan yang mereka lakukan. Bahkan ketika mereka sepakat untuk maju menjadi satu paket calon presiden dan calon wakil presiden hal itu dilakukan lebih intens. Tentu saja ini dimaksudkan untuk mendongkrak popularitas dan mendongkrak elektabilitas. Termasuk didalamnya adalah tour atau yang populer disebut dengan safari politik. Berbagai tokoh masyarakat maupun rakyat kecil disambangi dan diajak bicara demi mencari simpati. Pasangan ini juga menggunakan frase mitos dan hiperrealitas dalam setiap iklan yang dilakukan selama massa kampanye.

Penelitian ini akan membahas sejauh mana praktek mitos dan hiperrealitas dalam iklan pemilu tahun 2009 dengan judul "humblle" dan "mampu" yang dilakukan oleh pasangan Jusuf Kalla dan Wiranto. Kemudian bentuk-bentuk mitos dan hiperrealitas seperti apa yang dilakukan oleh pasangan ini.

\section{KERANGKA TEORI}

\section{Fakta dan Mitos}

Mitos berasal dari bahasa Yunani mythos yang berarti kata yang diucapkan. Pada awalnya, mitos selalu dilawankan dengan 
kata logos. Mitos adalah cerita seorang penyair sedangkan logos adalah laporan yang dapat dipercaya sesuai dengan kenyataan. Mitos juga diartikan sebagai cerita mengenai dewa-dewa, pahlawan-pahlawan dari zaman lampau. Melalui tradisi lisan yang panjang, mitos akhirnya mengendap dalam berbagai macam jenis sastra. (Hartoko dan Rahmato, 1986: 88).

Pada perkembangan selanjutnya mitos mempunyai makna lebih luas. Mitos tidak selalu mengenai cerita tentang asul-usul dewa-dewa atau simbol-simbol masa lalu. Pada kehidupan masyarakat modern pun mitosselaluada. Barthes(1981:93) menyatakan bahwa orang modern pun selalu dikerumuni oleh mitos-mitos, sehingga orang modern merupakan produsen sekaligus konsumen mitos.

Dalam komunikasi mitos adalah suatu sistem yang memberikan pesan berkenaan dengan aturan masa lalu, ide, ingatan, dan kenangan atau keputusan-keputusan yang diyakini. Dengan demikian mitos bukanlah suatu benda, konsep atau gagasan melainkan sebuah lambang dalam bentuk wacana (discourse) (Barthes, 1981: 93). Lambang dalam mitos tidak selalu tertulis, tetapi dapat berupa film, benda atau peralatan-peralatan tertentu, gambar dan lain sebagainya. Perlu ditegaskan bahwa mitos bukanlah suatu benda tetapi dapat dilambangkan dengan benda (Hasanudin, 1998: 2).

Dalam kehidupan sehari-hari mitos bukanlah perkara benar atau salah. Kebenaran dan ketidakbenaran tersebut berkaitan dengan proses terjadinya suatu mitos. Mitos pada hakikatnya merupakan suatu generalisasi dari suatu peristiwa yang dianggap pernah terjadi dan dianggap selalu terjadi (Junus, 1986: 95).

Dalam perspektif Barthesian, manusia selalu dikerumuni oleh mitos. Bahkan, dapat disimpulkan bahwa mitos tidak selalu terkait dengan manusia primitif. Mitos-mitos yang mengelilingi kehidupan manusia tidak hanya didengar dan dipahami dari orang-orang tua atau buku-buku tentang cerita lama melainkan ditemukan setiap hari di televisi, radio, pidato, percakapan, obrolan, dan tingkah laku manusia (Sunardi, 2007: 103).

Pemahaman atas mitos akan menyebabkan manusia mempunyai suatu prasangka tertentu terhadap hal yang dinyatakan dalam mitos. Hanya melalui persentuhan dengan hal tertentu tersebut, manusia dapat mengetahui ketepatan dan kekeliruan pemahaman terhadap mitos tersebut. Persentuhan dengan mitos yang terus menerus menyebabkan munculnya dua kemungkinan. Kemungkinan yang dimaksud yaitu persentuhan yang memperkuat mitos atau mitos pengukuhan (myth of concern) dan persentuhan yang meniadakan mitos atau mitos pembebasan (myth of freedom). Yang pertama, berusaha mempertahankan apa yang telah terwujud, sedangkan yang kedua menginginkan sesuatu yang baru dengan melepaskan diri dari apa yang telah ada (Junus, 1986: 92).

Pada bagian sebelumnya diuraikan bahwa mitos bukan suatu benda, melainkan dapat dilambangkan dengan benda. Oleh karena mitos selalu muncul dalam bentuk perlambangan, Barthes menganggap mitos sebagai bagian dari sistem semiotika. Sehingga selalu berkenaan dengan tiga hal yaitu, tanda, penanda, dan yang ditandai.

Dalam sistem semiotika, mitos dapat diuraikan ke dalam tiga unsur, yaitu: signifier, signified, dan sign. Untuk membedakan istilah-istilahyangsudahdipakaidalamsistem semiotika, Barthes menggunakan istilahyang berbeda untuk ketiga unsur tersebut yaitu, form, concepts, dan signification. Signifier sejajar dengan form, signified sejajar dengan concept dan sign sejajar dengan signification. Pembedaan istilah tersebut sebagai salah satu upaya menjelaskan perbedaan proses signification dalam sistem semiotika tingkat pertama dan tingkat kedua. Sistem semiotika tingkat pertama adalah linguistik, sistem semiotika tingkat kedua adalah sistem mitis yang mempunyai keunikan (Sunardi, 2007: 104).

Dengan demikian, mitos merupakan sejenis sistem ganda dalam semiotika yang terdiri atas sistem linguistik dan sistem semiotika. Untuk menghasilkan sistem mitis, sistem semiotika tingkat dua mengambil 
seluruh sistem tanda tingkat pertama dan dijadikan sebagai signifier (form). Sign diambil alih oleh sistem kedua menjadi form. Adapun concept diciptakan oleh pembuat atau pengguna mitos. Sign yang diambil untuk dijadikan form diberi nama lain, yaitu meaning. Meaning memberi penegasan bahwa kita mengetahui tanda hanya dari maknanya. Dalam pemahaman mitos, meaning berdiri di atas dua kaki, yakni di atas tingkat kebahasaan (sebagai sign), dan di atas tingkat sistem mitis (sebagai form) (Sunardi, 2007: 105).

Keterkaitan mitos dengan iklan cukup erat. Banyak iklan produk kecantikan yang memvisualisasikan bahwa wanita cantik itu jika tubuhnya tinggi semampai, kulit putih, rambut lurus dan kurus. Sehingga hal itu menjadi mitos, bahwa jika tidak memiliki kriteria tersebut diatas maka kualifikasi cantik tidak masuk. Begitujuga dalam politik. Banyak pemberitaan yang menyebutkan bahwa SBY ditahun 2004 adalah seorang satrio piningit. Seorang pemimpin pilihan tuhan yang diturunkan kebumi. Kemudian, pemimpin hebat itu adalah seperti Soekarno, sehingga banyak para tokoh politik yang mengklaim bahwa dia adalah titisan biologis atau idiologis dari Soekarno. Hal ini mudah dijumpai ketika banyak tokoh politik yang menggunakan baju seperti yang biasa digunakan oleh Soekarno.

\section{Realitas dan Hiperrealitas}

Mengacu istilah yang populer dari Baudrilard tentang 'hyperreality', iklan memiliki kaitan erat dengan istilah ini. Ketika berbicara tentang hiperrealitas, sebuah eksistensi akan bersinggungan dengan banyak hal tentang sesuatu yang asli dengan yang palsu, sesuatu yang nyata dengan yang tidak nyata. Iklan sebagai media yang memiliki misi untuk memberikan pencitraan yang bersifat komersil terhadap sesuatu produk mutlak memiliki nilai-nilai artistik yang mengundang ketertarikan khalayak (konsumen), paling tidak perhatian tehadap iklan tersebut, selanjutnya menyukai produk yang ditawarkan dan tahap terakhir adalah memilih produk tersebut, (Piliang, 2012: 130135).

Nilai-nilai artistik yang mutlak dimiliki sebuah iklan ini membutuhkan sebuah pengkondisian dan reproduksi kesadaran yang terus menerus melalui manipulasi simbol-simbol sehingga pesan yang dibawa iklan bisa tercapai dengan cara yang sangat halus. Baudrilard (dalam Storey: 2004, 244) memaknai hiperrealitas sebagai sebuah dunia yang berbeda, yaitu antara yang simulasi (tidak riil) dengan yang riil. Dimana antara yang riil dan yang tidak riil berjalan terus menerus dengan bergantian. Akibatnya yang riil dan yang tidak riil dijalani tanpa perbedaan. Kondisi ini seringkali menempatkan simulasi (yang tidak riil) dianggap lebih riil dibanding dengan riil itu sendiri, dan bahkan dianggap lebih baik atau ideal dari pada yang riil.

Ketika banyak keadaan tidak lagi selaras, di manaperbedaanantarayang nyatadanyang imajiner tidak ada lagi, realitas serta merta terkontaminasi oleh simulasi, maka dunia manipulasi atau dunia rekayasa menjadi hal yang nyata. Pada titik ini simulasi menjadi lebih mewakili dari pada realitas yang ada. Semisal, dalam sebuah iklan politik. Seorang tokoh yang pasts menjadi pemimpin adalah yang dekat dengan rakyat, sederhana, cerdas dan kharismatik. Simbol pemimpin tersebut memiliki karakteristik spesifik yang pada dunia nyata sebenarnya mungkin sangat langka.

Jean Baudrillard menggunakan istilah hiperrealitas untuk menjelaskan perekayasaan makna di dalam media. Hiperrealitas media menciptakan suatu kondisi sedemikian rupa sehingga kondisinya semakin remang-remang, kepalsuan-kepalsuan informasi dianggap sebagai kenyataan, isu-isu yang beredar lebih dipercayai daripada kebenaran faktual. Sehingga publik akhirnya tidak bisa membedakan mana kebenaran sejati dengan kebenaran semu.(Piliang, 2005: 222).

Lebih lanjut ketika hiperrealitas sudah menjadi hal yang jamak dan perkembangan tekhnologi semakin cepat terjadi, maka menurut Baudrillad, keadaanya akan 
berubah pada tekhnologi simulasi. Titik tekan tekhnologi simulasi ini berada pada penciptaan model-model kenyataan yang tanpaasal-usulataureferensirealitas, (Piliang, 2012: 126). Jika kita tarik dalam konteks media, simulasi merupakan penciptaan kesan nyata yang tidak mengacu pada realitas sesungguhnya yang terjadi, sehingga hasilnya seolah-olah menjadi semacam realitas kedua atau yang juga disebut dengan simulakrum. Ketika simulakrum telah mampu menggeser realitasyang sesungguhnya pada titik tertentu ia akan lebih dipercayai publik daripada realitas yang sesungguhnya, meskipun simulakrum ini adalah realitas artifisial.

Hiperrealitas yang terjadi terpaksa telah menyeret masalah-masalah sosio-kultural yang berkaitan dengan nilai, makna dan pengetahuan. Yasraf Amir Piliang membagi permasalahan sosio-kultural ini menjadi beberapa bagian. Pertama, disinformasi, artinya simulakrum yang terjadi terus menerus pada satu titik akan menimbulkan kondisi ketidakpercayaan pada informasi itu sendiri, bahkan pada setiap informasi.

Kedua, adanya depolitisasi dimana akhirnya hiperealitas media menciptakan model komunikasi satu arah, dimana pembaca berposisi sebagai pembaca yang pasif. Dimana resistensi pembaca cenderung berada pada titik terendah karena telah bercampurnya antara realitas dan simulakrum, antar kebenaran dan kepalsuan, maupun fakta dan rekayasa.

Ketiga, adanya banalitas informasi dimanainformasiyangdisampaikanbukanlah informasi yang dibutuhkan oleh masyarakat. Informasi-informasi yang disampaikan hanyalah informasi sampah dan tidak ada manfaatnya (banality of information).

Keempat, terjadinya fatalitas informasi yang mana informasi yang disampaikan cenderung berlebihan dan akhirnya tidak mempunyai fungsi yang jelas. Fatalitas informasi dapat juga diartikan dengan kecenderungan pembiakan informasi kearah titik ekstrem, yaitu ke arah yang melampaui nilai guna, fungsi dan maknanya yang akhirnya menggrirng ke arah bencana (catastrophe) berupa kehancuran sistem komunikasi itu sendiri.

Selanjutnya yang kelima adalah skizofrenia, yaitu putusnya rantai pertandaan. Dikatakan rantai pertandaan putus, ketika penanda tidak lagi mempunyai korelasi dengan petanda dengan ikatan yang pasti, maka yang tercipta adalah kumpulan informasi yang tidak bermakna.

Keenam adanya hipermoralitas, dimana salah satu konsekuensi dari wacana kecepatan dan keharusan informasi adalah kecenderungan dekonstruksi terhadap berbagai kode-kode sosial, moral maupun kultural. Kemudian media yang telah tercerabut dari struktural moral menciptakan semacam kondisi hipermoralitas, yaitu lenyapnya batas-batas moral itu sendiri didalam wacana ketelanjangan media. (Piliang, 2005: 225-227).

\section{METODE}

Adapun analisisnya mengunakan semiotika. Untuk mengkaji makna tandatanda politik pencitraan, penelitian ini menggunakan metode analisis semiotika yang mengacu pada teori Roland Barthes, dimana dirasa cocok untuk meneliti iklan. Dengan pemaknaan dua tahap denotasi dan konotasi yang digunakan oleh Roland Barthes dalam teori semiotikanya, Roland Barthes menelusuri makna dengan pendekatan budaya yaitu semiotika makro, dimana Barthes memberikan makna pada sebuah tanda berdasarkan kebudayaan yang melatarbelakangi munculnya makna tersebut, (Barthes: 2012, 131-137).

Alasan digunakan penelitian semiotika, pertama bahwa obyek yang akan di kaji untuk diungkap maknanya adalah tanda, lambang, bahkan simbol yang ada di dalam iklan kampanye pemilu presiden 2009. Sehingga rangkaian tanda yang terinterpretasikan menjadi suatu jawaban atas pertanyaan nilai-nilai ideologi dan kultural yang berada di balik sebuah teks. Hal ini tentu berbeda hasilnya jika yang digunakan adalah metode analisis isi atau analisis wacana. Analisis isi tidak dapat dipakai untuk menguji hubungan antar variabel, sehingga tidak 
dapat melihat sebab akibat, hanya dapat melihat kecenderungan, (Eriyanto, 2011: 15-16). Adapun analisis wacana merupakan metode untuk mengkaji wacana yang terkandung dalam pesan-pesan komunikasi, baik secara tekstual maupun kontekstual dengan tujuan menjelaskan dimensi linguistik kewacanaan akan fenomena sosial, kultural dan proses perubahan dalam modernitas terkini (Jorgensen dan Philips, 2007: 116). Artinya bahwa analisis isi hanya mendeskripsikan isi komunikasi sedangkan analisis wacana sebatas melihat wacana apa yang dimunculkan kepada publik. Kedua, model Roland Barthes yang dipilih, karena model inilah yang memberikan kedalaman ketika memaknai sebuah iklan dengan mendasarkan pada fenomena sosial terkait simbol yang mencerminkan mitos dan hiperrealitas.

Analisis semiotika model Roland Barthes, memfokuskan diri pada gagasan tentang signifikasi dua tahap (two order of signification). Signifikasi tahap pertama merupakan hubungan antara signifier dan signified di dalam sebuah tanda, sehingga mengambarkan realitas eksternal. Barthes menyebutnya sebagai denotasi, yaitu makna paling nyata dari tanda-tanda. Adapun signifikasi tahap kedua, Barthes menyebutnya konotasiyaitugambaraninteraksiyang terjadi ketika tanda bertemu dengan kenyataan atau emosi dari pemirsa serta nilai-nilai dari kebudayaan. Konotasi memiliki nilai yang subyektif atau intersubyektif, jika denotasi adalah apa yang digambarkan tanda terhadap subjek, sedang konotasi adalah bagaimana sebuah tanda menggambarkannya. (Sobur, 2004: 63-71). Penelitian ini akan disandarkan pada signifikansi tahap kedua. Sehingga diharapkan ketika tanda berinteraksi dengan kenyataan dan nilai-nilai kebudayaan akan ditemukan konstruksi politik pencitraan yang sesungguhnya.

Adapun iklan yang diteliti adalah iklan pasanganJK-Wirantoyang berjudul "Humble" dan "mampu". Sedangkan proses analisisnya yaitu dengan mengambil beberapa scan gambar dan juga potongan suara dalam iklan. Kemudian mencari makna denotasi terlebih dahulu kemudian digali dan dianalisis mengenai makna konotasinya.

\section{HASIL DAN PEMBAHASAN}
Gambaran Umum Pasangan Muhammad Jusuf Kalla berpasangan dengan Wiranto atau disingkat pasangan (JK- Win).

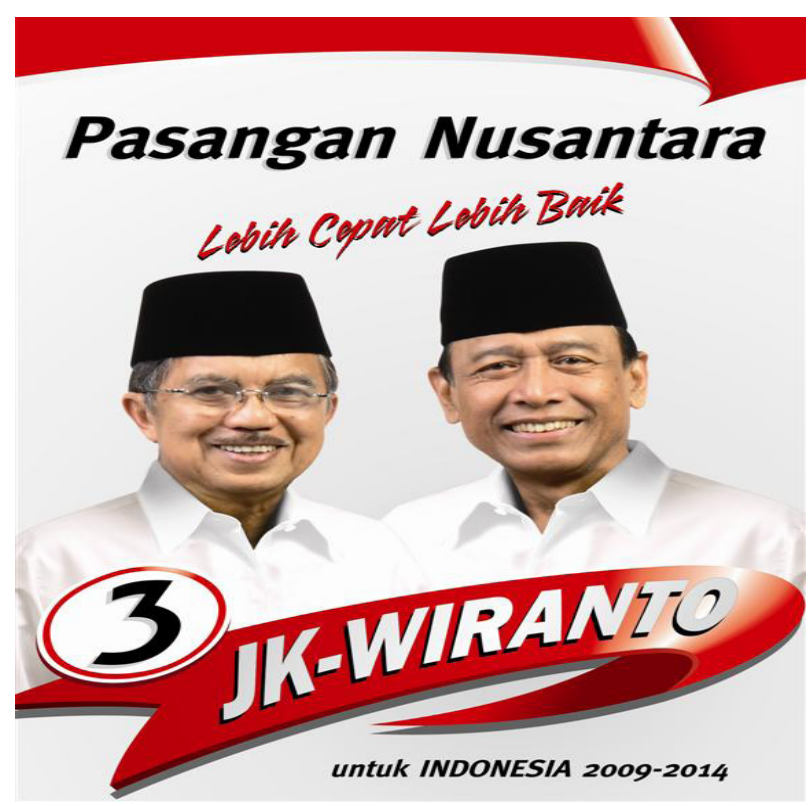

Gambar 1. Logo pasangan JK-Wiranto

Calon presiden Muhammad Yusuf Kalla lahir di Makasar 15 Mei 1942. Terlahir dari keluarga pedagang membuat Jusuf Kalla hidup dalam kecukupan. Namun konon orang tuannya sangat disiplin dalam mendidik Jusuf Kalla, sehingga di usia 8 tahun Jusuf Kalla sudah diajari orang tuannya menjadi kasir. JK menamatkan kuliah di Universitas Hasanudin dan semasa muda aktif di gerakan mahasiswa. Kiprahnya hampir dia habiskan untuk berbisnis dengan mendirikan beberapa perusahaan. Namun dia sempatkan juga untuk terjun di dunia politik dengan menjadi anggota DPR dari Golkar sejak tahun 1982 sampai 1999.

$$
\text { Saat pemerintahan Presiden }
$$
Abdurrahman Wahid ditunjuk menjadi menteri Perindustrian dan Perdagangan. Setelah Megawati menjadi presiden, JK ditunjuk menjadi Menko Kesra. Disaat menjabat Menko Kesra, JK digaet oleh SBY untuk maju sebagai calon wakil presiden. 
Bersama dengan SBY pada pemilu 2004 terpilih menjadi presiden dan wakil presiden sampai tahun 2009. Karena langkah dan gayanya dalam memimpin, JK dijuluki sebagai "the real presiden". Konon hal inilah yang membuat SBY tidak suka, sehingga ditahun 2009 SBY memilih Budiono untuk mendampinginya maju di pilpres. (Dharmawan, 2004: 263-275).

Jendral (Purn) Wiranto adalah calon wakil Presiden yang mendampingi Jusuf Kalla. Wiranto sendiri lahir di Yogyakarta 4 April 1947. Sejak kecil Wiranto bercitacita sebagai tentara. Dan terbukti pada tahun 1968 Wiranto lulus AKABRI. Tak berbeda jauh dengan SBY dan Prabowo, karir militer Wiranto terbilang cukup cemerlang. Salah satunya adalah menjadi ajudan presiden Soeharto dan puncaknya menjadi Menhankam/Pangab pada masa presiden Soeharto. Disaat Wiranto sebagai panglima ABRI, gerakan revormasi merupakan ujian terberat yang dialaminnya. Krisis ekonomi, unjuk rasa mahasiswa dan kerusuhan melanda diseantero Indonesia, memaksa Wiranto untuk bertindak tegas, tepat dan cermat.

Pada tanggal 18 Mei 1998, presiden Soeharto menandatangani surat perintah untuk mengamankan unjukrasa dan kerusuhan. Surat tersebut memberi peluang Wiranto untuk menertibkan dan mengambil langkah-langkah untuk mengendalikan situasi Negara. Namun Wiranto tidak menggunakannya dan justru mendukung Soeharto untuk mundur dan menyerahkan kekuasaan pada wakilnya, BJ Habibi.

Pada masa pemerintahan presiden Habibi, Wiranto tetap dipercaya sebagai Menhankam/Pangab. Pada masa presiden Abdurrahman Wahid dipercaya sebagai Menko Polhukam sampai tahun 2000. Ditahun 2004, Wiranto mengikuti konvensi yang diadakan oleh partai Golkar dan menjadi pemenangnya, sehingga didaulat menjadi calon presiden dengan Solahudin Wahid sebagai calon wakil presiden. Namun hasil pemilu 2004 menempatkan SBY dan JK sebagai presiden. Kemudian Wiranto mendirikan partai Hanura yang menjadi kendaraannya sebagai calon presiden mendampingi JK pada pemilu 2009. (Dharmawan, 2004: 3-75).

Pasangan ini diusulkan oleh koalisi dari partai Golkar, PKNU dan Partai Hanura dengan presentasi perolehan kursi DPR RI sebanyak 22, 32\%. Kekayaan yang dimiliki oleh JK sebesar 315 milyar dan Wiranto memiliki kekayaan sebesar 82 milyar. Pasangan ini mengambil Visi: Indonesiayang adil, mandiri dan bermartabat. Misi yang akan dilakukan oleh pasangan ini adalah:

1. Tercapainya ekonomi bangsa yang mandiri, berdaya saing, dan berkeadilan demi terwujudnya kesehjateraan masyarakat.

2. Mewujudkan Pemerintahan yang bersih, berwibawa, demoratis dengan pengambilan keputusan yang cepat dan tepat.

3. Mewujudkan kesejahteraan sosial, ketahan budaya, dan otonomi daerah yang sehat, efesien dan efektif untuk lebih memantapkan integrasi nasional yang menjamin kebhinekaan.

4. Mewujudkan bangsa yang aman tentram dan damai dengan penegakkan hukum dan HAM.

5. Mewujudkan Indonesia yang dihormati dan disegani oleh bangsa-bangsa lain dalam bidang ekonomi dan politik.

Adapun agenda kebijakan yang diambil selama lima tahun jika terpilih adalah:

1. Ekonomi: Membangun ekonomi kerakyatan, membangun kedaulatan pangan dan energi, meningkatkan daya saing produk dalam negeri, menciptakan struktur ekonomi nasional yang adil.

2. Politik dan hukum: Memperkuat sistem presidensiil yang didukung sistem kepartaian yang sederhana, menata kembali fungsi-fungsi lembaga negara, reformasi birokrasi untuk mewujudkan penyelenggara Negara yang tangkas, tanggap dan cepat.

3. Pertahanan dan Keamanan: Menjaga kedaulatan dan keutuhan NKRI, Modernisasi alat utama sistem 
persenjatahan TNI-Polri, Peningkatan anggaran pertahanan dan keamanan.

4. Pendidikan: Meningkatkan kualitas dan pemerataan pendidikan, meningkatkan penyediaan pendidikan yang terjangkau.

5. Sosial Budaya: Meningkatkan solidaritas sosial kesetiakawanan dan memupuk semangat nasionalisme.

6. Kesehatan: Meningkatkan penyediaan sarana dan prasarana kesehatan, dokter dan tenaga medis yang memadai bagi daerah tertinggal.

7. Pemuda dan olahraga: Pengembangan kepeloporan pemuda, peningkatan prestasi olahraga (Sumber, Kompas 2 Juni 2009).

Susunan tim sukses pasangan JK Wiranto adalah sebagai berikut:

1. Dewan Penasihat: Surya Paloh (Koordinator), Bambang W Soeharto, Aburizal Bakrie, Sri Sultan Hamengku Buwono X, Abdul Gafur, Siswono Yudo Husodo, Soebagyo HS, Tantri Abeng, Teuku Bulganon Amir, Ja'far D Assegaf, Chaeruddin Ismail, Toeti Aditama, Sofyan Wanandi, Soleh Solahuddin, Moh. Taha, Kuneng Bau Massepe, Rugaya Usman, Achmad Sutarmadji, Abu Hartono, Ismael Hasan, MS Hida.

2. Dewan Pengarah: Agung Laksono (Koordinator), Fachrul Razi, Andi Mattalata, Fuad Bawazier, Muladi, Sumarsono, Yus Usman Sumanegara, Theo L Sambuaga, Muhammad AS Hikam, Aksa Mahmud, Amidhan, Suadi Marasabessy, KH Aziddin, Hasanuddin Massaile, Tadjuddin Noer Said, E Agustini Syarwan Hamid, Andi Ahmad Dara, Paskah Suzetta, Samuel Koto, Agus Gumiwang Kartasasmita, Djafar Badjeber, Yamin Tawary, Arifin Tarigan, Rully Chairul Azwar, Siti Chatidjah, Ryaas Rasyid, Arwindrasti Bandjar, dan Uu Rukmana.

\section{Tim Kampanye:}

a. Fahmi Idris (Koordinator), Syamsul Mu'arif, Abu Hartono, Alwi Hamu, M Basri Sidehabi, Tutty Alawiyah AS, Burhanuddin Napitupulu, dan Nico
Daryanto.

b. Wakil Ketua: Ary Mardjono, Syamsul Mu'arif, Abu Hartono, Alwi Hamu, Basri Sidehabi, Tutty Alawiyah, Burhanuddin Napitupulu dan Nico Daryanto.

c. Sekretaris: Iskandar Mandji (Koordinator), Pieter LD Wattimena, Danny P Thaharsyah, Simon Patrice Morin, Achmad Sukma Gondewa, Ibnu Munzir, dan Farida Syamsi Chadaria.

d. Bendahara: Benny Prananto (Koordinator), Ahmad Zaky, Dedi Andi Pratiwi, dan Yendra Fachmi (okezone.com: 2009).

e. Koordinator Bidang advokasi dan hukum: Chairuman Harahap.

f. Koordinator Bidang kajian: Thomas Suyatno

g. Koordinator Bidang pencitraan: Iwan A Sudirwan.

h. Koordinator Bidang hubungan masyarakat dan juru bicara: Fuad Bawazier. (detik.com, 2009).

Adapun perolehan suara setelah dilakukan pemungutan suara pada 8 Juli 2009, KPU menetapkan bahwa pasangan Megawati-Prabowo memperoleh 32.548.105 suara atau 26,79\%, SBY-Budiono memperoleh suara sebanyak 73.874 .562 suara atau $60,80 \%$, sedangkan JK-Wiranto mendapatkan suara sebanyak 15.081. 814 atau 12,41\%, (Cengara, 2011: 207). 


\section{Analisis makna Denotasi}

\begin{tabular}{|c|c|c|}
\hline Judul Iklan & Obyek Visual & Makna Denotasi \\
\hline \multirow[t]{5}{*}{ Humble } & & $\begin{array}{l}\text { Foto masa muda JK. Dengan kumis tipis khas JK } \\
\text { memakai pakaian setelan jas dan dasi }\end{array}$ \\
\hline & & $\begin{array}{l}\text { JK berdiskusi dengan ibu-ibu yang lusuh. Ibu-ibu itu } \\
\text { tersenyum mendengan ucapan JK }\end{array}$ \\
\hline & & $\begin{array}{l}\text { JK sedang melihat masterplan pembangunan } \\
\text { pembangkit listrik. Terlihat JK memberikan instruksi }\end{array}$ \\
\hline & & $\begin{array}{l}\text { JK dan Wiranto sedang melambaikan tanggan di tugu } \\
\text { proklmasi. Mereka berdua memakai kopyah dan baju } \\
\text { lengan panjang }\end{array}$ \\
\hline & & $\begin{array}{l}\text { JK melambaikan tanggannya kepada para } \\
\text { pendukungnya. Dengan pakaian khas yaitu lengan } \\
\text { panjang dipadu dengan kopyah hitam JK tersenyum } \\
\text { pada pendukungnya. }\end{array}$ \\
\hline \multirow[t]{4}{*}{ Mampu } & & $\begin{array}{l}\text { Seorang pemuda terlihat dari jendela. Sambil } \\
\text { memegang tralis jendela pemuda itu terlihat lesu dan } \\
\text { penuh masalah }\end{array}$ \\
\hline & & $\begin{array}{l}\text { Seorang ibu rumahtangga menyaksikan layar TV. } \\
\text { Di TV tersebut terlihat JK sedang menyampaikan } \\
\text { programnya. }\end{array}$ \\
\hline & & $\begin{array}{l}\text { Seorang perempuan sedang memeluk anaknya yang } \\
\text { memakai pakaian sekolah dengan gembira. }\end{array}$ \\
\hline & 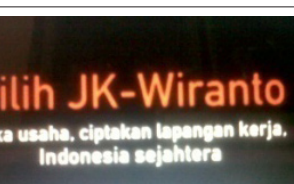 & $\begin{array}{l}\text { Visualisasi "pilik JK-Wiranto. Buka usaha, ciptakan } \\
\text { lapangan kerja, indonesia sejahtera” }\end{array}$ \\
\hline
\end{tabular}




\begin{tabular}{|c|c|c|}
\hline Judul Iklan & Obyek Verbal & Makna Denotasi \\
\hline \multirow[t]{4}{*}{ Humble } & Saya memang berbeda & $\begin{array}{l}\text { Jusuf Kalla merasa memiliki gaya } \\
\text { kepemimpinan yang berbeda }\end{array}$ \\
\hline & $\begin{array}{l}\text { Perawakan saya tidak seperti } \\
\text { pemimpin yang diidolakan }\end{array}$ & $\begin{array}{l}\text { JK merasa bukan sosok pemimpin yang } \\
\text { diidolakan secara fisik. Karena tubuhnya } \\
\text { kecil. }\end{array}$ \\
\hline & $\begin{array}{l}\text { Banyak yang bilang saya cepat dan } \\
\text { tegas serta lugas dalam mengambil } \\
\text { keputusan, saya bilang itu hanyal } \\
\text { cara guna mengangkat rakyat dari } \\
\text { ketertinggalan }\end{array}$ & $\begin{array}{l}\text { Banyak orang yang melihat JK adalah } \\
\text { sosok pemimpin yang tegas dan cepat } \\
\text { dalam mengambil tindakan. Sedangkan JK } \\
\text { mengklaim bahwa itu merupakan cara untuk } \\
\text { menuntaskan permasalahan rakyat secara } \\
\text { cepat. }\end{array}$ \\
\hline & $\begin{array}{l}\text { Saya yakin kita bisa lebih baik dari } \\
\text { sekarang, seandainya saya diberi } \\
\text { kesempatan memimpin negeri ini. }\end{array}$ & $\begin{array}{l}\text { JK merasa bahwa dia bisa membawa } \\
\text { pemerintahan selama ini seandainya diberi } \\
\text { kesempatan menjadi presiden. }\end{array}$ \\
\hline \multirow[t]{4}{*}{ Mampu } & $\begin{array}{l}\text { Pemuda adalah tulang punggung } \\
\text { bangsa. Namun masih banyak } \\
\text { diantara mereka yang belum } \\
\text { mempunyai modal dan kesempatan }\end{array}$ & $\begin{array}{l}\text { Pemuda merupakan generasi penerus } \\
\text { bangsa. Namun mereka banyak yang masih } \\
\text { menderita. }\end{array}$ \\
\hline & $\begin{array}{l}\text { Oleh karena itu jika saya terpilih } \\
\text { jadi presiden saya akan mengulirkan } \\
\text { program mampu }\end{array}$ & $\begin{array}{l}\text { JK apabila terpilih menjadi presiden akan } \\
\text { mengulirkan program untuk para pemuda } \\
\text { yang masih kesusahan mencari penghasilan } \\
\text { hidup }\end{array}$ \\
\hline & $\begin{array}{l}\text { Mampu adalah modal bantuan usaha } \\
\text { senilai 30-40 juta rupiah }\end{array}$ & $\begin{array}{l}\text { Nama program JK adalah "mampu", yang } \\
\text { merupakan pemberian modal usaha antara } \\
\text { 30-40 juta }\end{array}$ \\
\hline & Saya yakin pemuda pasti mampu & $\begin{array}{l}\text { JK memberi keyakinan bahwa para pemuda } \\
\text { mampu mengangkat derajatnya. }\end{array}$ \\
\hline
\end{tabular}

\section{Analisis Makna Konotasi}

\section{JK Huble}

Iklan ini berdurasi 6o detik. Dalam iklan ini divisualisasikan, bahwa JK sambil duduk bercerita mengenai dirinya dan apa yang telah dilakukan selama menjadi wakil presiden.

Suara JK mengawali iklan, "Saya memang berbeda”. JK ingin menegaskan bahwa dia adalah sosok pribadi dan pemimpin yang unik. Hal ini dipertegas dengan kalimat, "Perawakan saya tidak seperti pemimpinyang diidolakan”. SBY adalah sosok yang meliki postur tubuh besar dan tinggi. Dalam bahasa lain gagah dan ganteng, sehingga media banyakyang memberitakan bahwaSBYadalah idola para ibu-ibu. Adapun JK menegaskan bahwa perawakannya berkebalikan dengan SBY. JK perawakan kecil, sehingga kalau dari postur tubuh tidak gagah dan tidak pantas menjadi presiden.

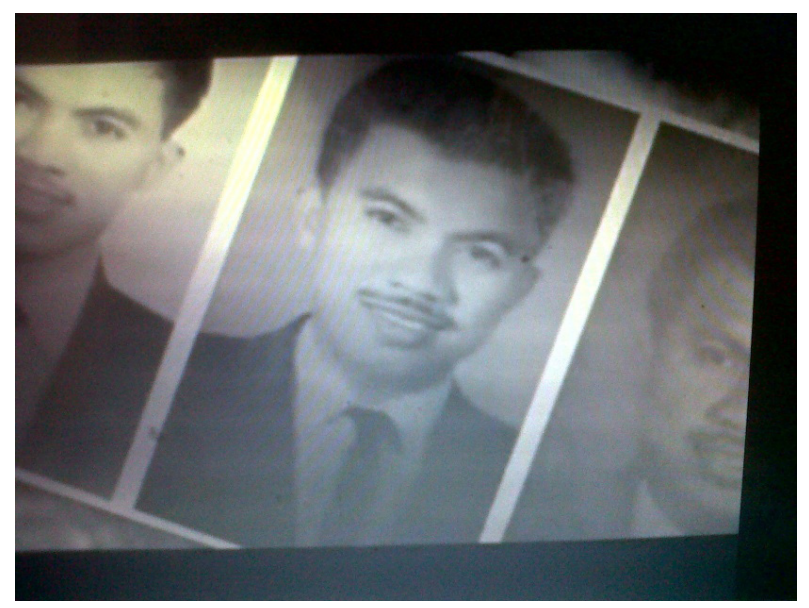

Gambar 2. Visualisasi foto masa remaja JK.

Bahkan dalam iklan ini, JK menunjukan foto masa mudannya dengan kumis khasnya. Dengan memakai jas dan berdasi. Jika dilihat dari sisi lain, JKadalah sosok yang berasal dari keluarga berduit. Dan kenyataannya memang begitu. Dia adalah keluarga yang terlahir 
dari pengusaha, dan saat mencalonkan kekayaannya yang terbanyak bila dibanding calon lain.

JK mengatakan "Banyak yang bilang saya cepat dan tegas serta lugas dalam mengambil keputusan, saya bilang itu hanyal cara guna mengangkat rakyat dari ketertinggalan”. Pernyataan JK ini mengacu pada pemberitaan media ketika JK menjabat wakil presiden. Saat itu media menilai JK adalah pemimpin yang cepatdalam mengambilsebuah kebijakandan dinilai menggunakan cara-cara yang berbeda dalam menyelesaikan masalah. Bahkan ada pengamatyangmengibaratkanpemerintahan saat itu seperti mobil, SBY berperan sebagai rem dan JKadalah Gas. Sehingga banyak yang memberi apresiasi kepada JK yang cepat dan tanggap. Hal ini dijadikan bahan kampanye dalam iklan tersebut. JK mengklaim bahwa itu merupakan cara untuk mengatasi masalah dengan cepat.

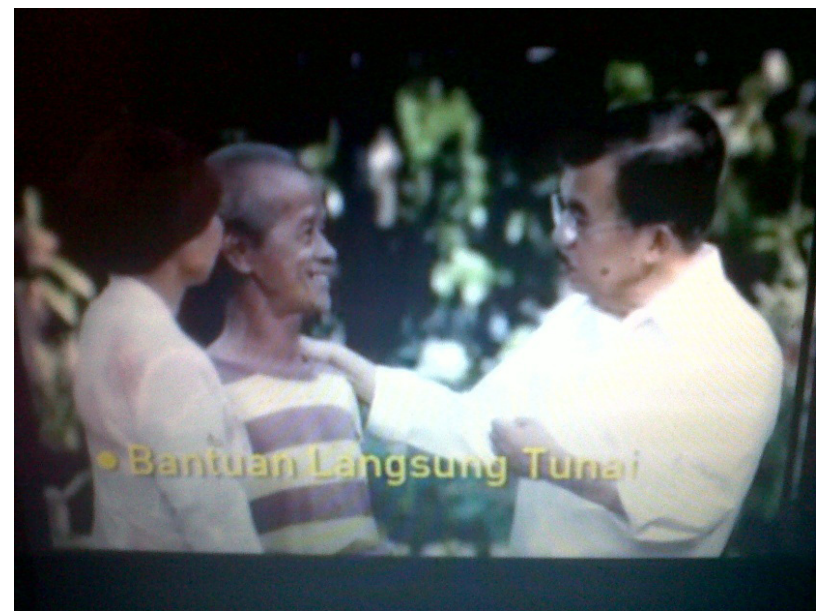

Gambar 3. Visualisasi kedekatan JK dengan rakyat.

Gambar sosok JK bersapa seorang perempuan dan lelaki tua bertuliskan "bantuan langsung tunai", merupakan bentuk kedekatan JK bersama rakyat kecil. Digambarkan bahwa dengan senyuman lelaki tua, merupakan bentuk kegembiraan rakyat atas didapatkannya bantuan langsung tunai. Padahal disisi lain bantuan langsung tunai merupakan kebijakan pemerintah, artinya SBY juga berhak mengklaim kebijakan tersebut. Seolah tidak maukalah dengan SBY yang saat itu sama-sama dengan JK dipemerintahan, JK mengklaim keberhasilan selama dia menjabat sebagai wakil presiden. Selain itu kebijakan tersebut diambil atas kompensasi kenaikan harga BBM. Sangat mungkin yang mendapatkan BLT merasa senang, namun yang tidak mendapatkan akan sebaliknya. Hal ini merupakan bentuk generalisasi dikarenakan kebijakan yang dia klaim sebagai keberhasilannya tersebut tidak mungkin terlaksana tanpa persetujuan SBY dengan dibantu oleh beberapa eleman pemerintahan.

Suara JK yang mengatakan, "Saya yakin kita bisa lebih baik dari sekarang, seandainya saya diberi kesempatan memimpin negeri ini”, diikuti gambar JK sedang memanen didampingi oleh Sultan Hamengkubuwono X dan beberapa orang seperti gambar dibawah ini. JK ingin menyampaikan bahwa dia selama ini telah melakukan sesuatu untuk bangsa. Dan JK yakin jika dipilih kembali maka akan lebih baik bangsa dan negara ini. JK mengatakan kalau apa yang dilakukan menurut orang termasuk cepat, dengan berusaha merendah dia mengatakan bahwa itu adalah semata cara untuk menyelesaikan masalah. Dan jika dia diberi amanah untuk jadi presiden dia meyakinkan bahwa Indonesia bisa lebih baik.

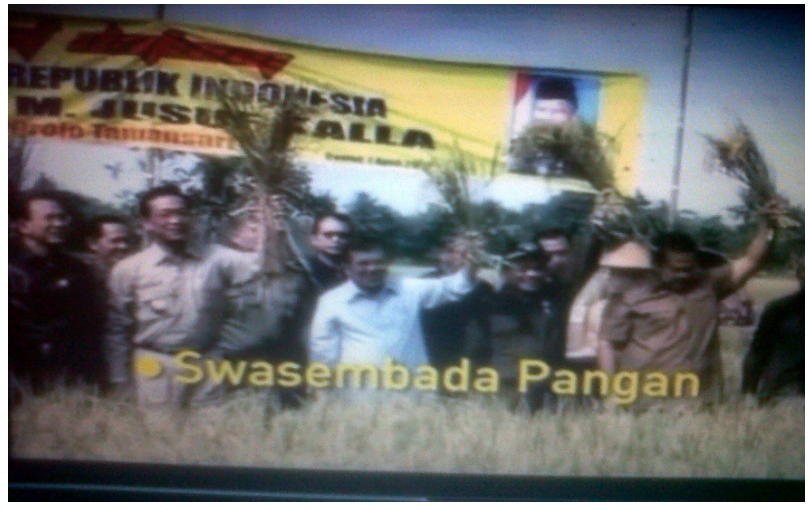

Gambar 4. Visualisasi JK sedang melakukan panen raya

Gambar JK sedang memanen padi, adalah bentuk simbol swasembada pangan. Ini agak kontras dengan realitas. Kenyataanya Indonesia dalam masalah beras masih bergantung dari impor. 


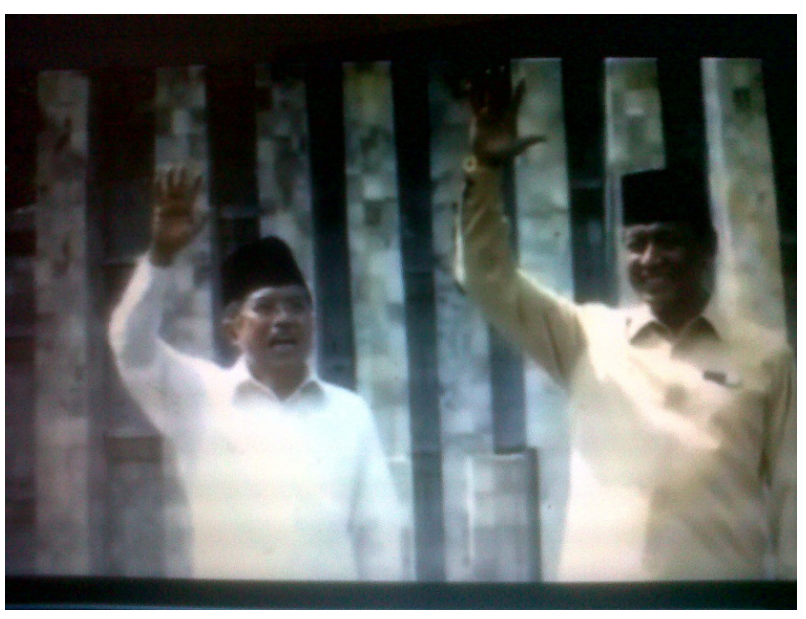

Gambar 5. Visualisasi JK dan Wiranto di tugu Proklamasi.

Gambar JK dan Wiranto sedang melambaikan tangan di tugu proklamasi. Hal ini dimaksudkan bahwa pasangan ini adalah sosok nasionalis dan negarawan. Dapat dikatakan nasionalis mengingat tugu proklamasi adalah tonggak awal kemerdekaan Indonesia, dimana didalamnya terdapat berbagai ragam suku, agama, ras dan adat istiadat. Pasangan ini ingin berdiri diatas semua golongan. Dikatakan negarawan karena tugu proklamasi mengingatkan kita kepada beberapa tokoh bangsa yang merupakan negarawan. Disana para negarawan memproklamirkan kemerdekaan Indonesia. Pasangan ini ingin membuat bangsa Indonesia merdeka seutuhnya, sesuai dengan cita-cita para proklamator bangsa.

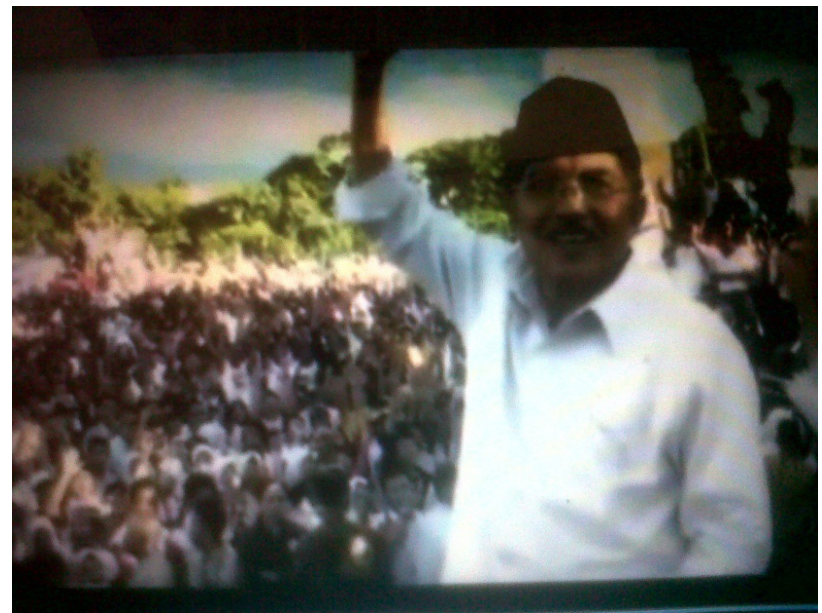

Gambar 6. Visualisasi JK sedang berkampanye.
Menjelang akhir iklan, terlihat gambar JK sedang melambaikan tangan sambil tersenyum diatas panggung. Dihadapannya ada ribuan massa. Dari gambar ini, JK ingin menunjukan bahwa dia juga memiliki massa yang banyak, yang akan mendukung dan memenangkannya. Dengan pakaian putih dan songkok hitam menjadi pakaian ciri khasnya. Baju lengan panjang, dilipat. Hal ini mengindikasikan bahwa JK adalah sosok pekerja lapangan. Bukan pekerja dibalik meja kantor.

\section{JK Mampu}

Iklan ini berdurasi 6o detik. Visualisasi iklan pertama-tama ditampilkan sosok pemuda yang berpakaian rapi sedang berjalan sambil membawa berkas lamaran. Dia keliling untuk menjacri pekerjaan. Suara Cut Tari terdengar,"Pemuda adalah tulang punggung bangsa. Namun masih banyak diantara mereka yang belum mempunyai modal dan kesempatan”. Diiring ilustrasi gambar seorang pemuda merenung dekat jendela dengan wajah menunduk, murung dan tatapan kosong.

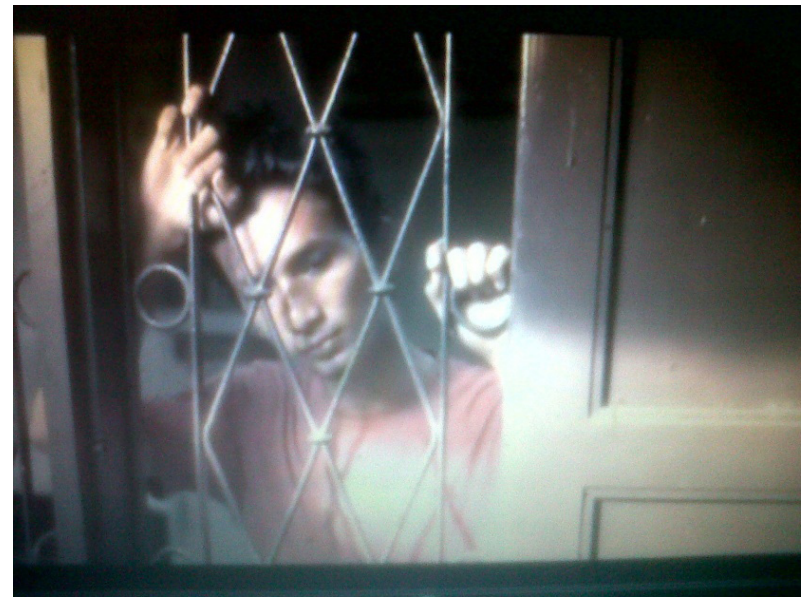

Gambar 7. Visualisasi pemuda sedang sedih karena miskin.

Gambaran tersebut ingin menunjukan jika selama ini masih banyak rakyat yang menderita. Dan salah satu sasaran iklan pasangan ini adalah pemuda. Hal ini tepat, karena jumlah pemuda di Indonesia adalah golongan usia yang mayoritas. Dan pasangan ini membidik para pemuda untuk mendulang suara. Dan isuyang digulirkanadalah masalah 


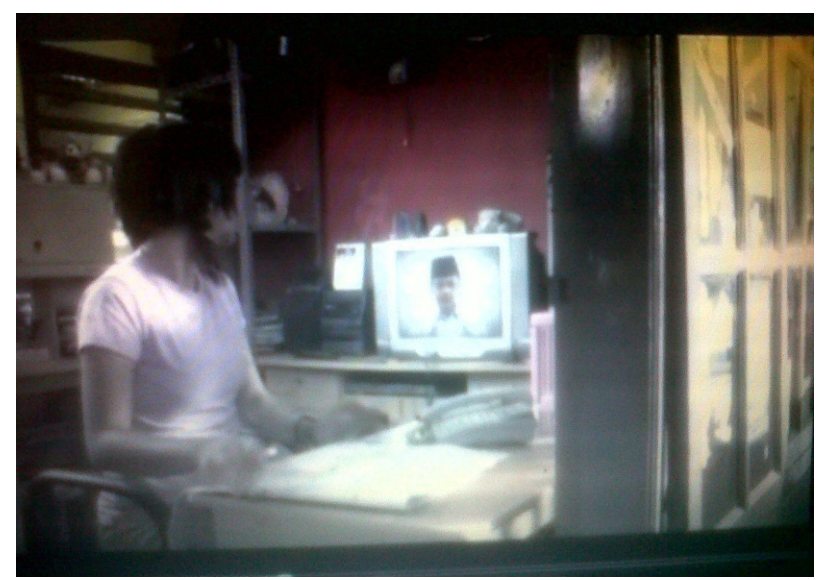

Gambar 8. Visualisasi ibu rumah tangga menyaksikan berita tentang program JK.

Sesaat kemudian seorang ibu rumah tangga menyaksikan siaran televisi yang berisi JK berbicara tentang misinya. JK mengatakan, "Oleh karena itu jika saya terpilih jadi presiden saya akan mengulirkan program mampu". Media televisi adalah salah satu media massa yang memiliki keunggulan, selain sangat evektif juga massif untuk menyampaikan sebuah informasi. JK menggunakannya untuk menyampaikan programnya jika terpilih. Dan memang benar, mulai dari warga miskin sampai orang kaya, di warung, di rumah, dikantor dan ditempattempat umu banyak televisi. Seorang ibu rumah tangga sedang menyaksikan televisi dirumahnya sambil melakukan aktivitas kesehariannya.

Pernyataan JK di televisi disambut gembira oleh pemirsa. Seorang ibu sedang memeluk anaknya, karena melihat ada kesempatan untuk menyambung hidup bagi anaknya dengan adanya program "mampu" yang digulirkan JK-Wiranto.

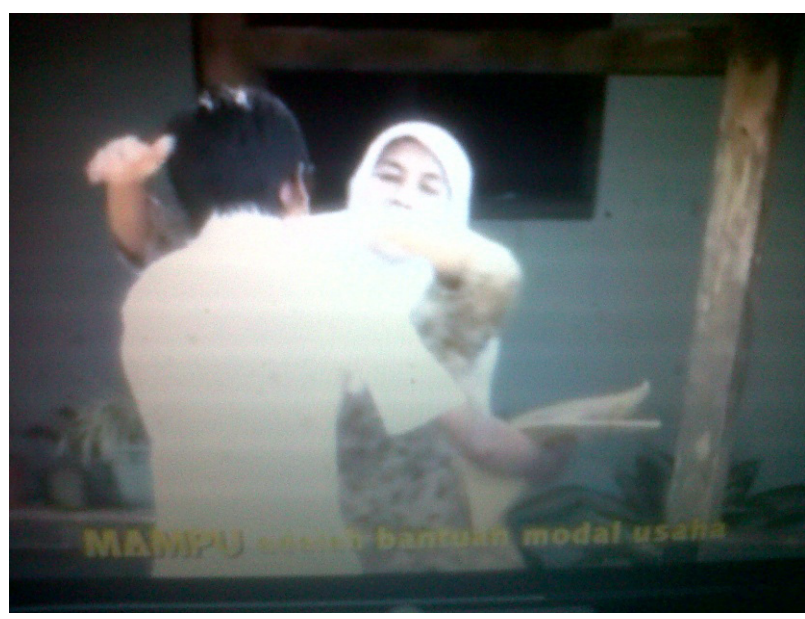

Gambar 9. Visualisasi ibu rumah tangga bahagia mendengar program JK.

Bersamaan dengan selesainya JK berbicara, terdengar suara illustrator yang menjelaskan program "mampu". "Mampu adalah modal bantuan usaha senilai 30-40 juta rupiah". Dimana modal usaha sebesar 3040 juta tersebut diperuntukan bagi lulusan SMP, SMK, SMA, pesantren dan korban PHK. Mengingat indonesia merupakan negara berkembang dengan jumlah penduduk yang banyak, tentunya jumlah pemuda yang tidak memiliki kesempatan melanjutkan pendidikan, dan disisi lain lapangan pekerjaan juga terbatas. Ini menjadi alasan pasangan ini mengulirkan program bantuan modal usaha.

Ada satu hal sebenarnya yang juga penting, apabila program ini diperuntukan bagi para pemuda yang putus sekolah alangkah lebih tepat jika bagi yang putus sekolah diberi bantuan beasiswa untuk melanjutkan sekolah. Sedangkan bagi yang sudah selesai sekolah, maka baru diberi modal usaha.

Di akhir iklan JK menyampaikan ucapan penutup dengan memberi harapan pada rakyat "Saya yakin pemuda pasti mampu”. Bersamaan dengan gambar iklan yang bertuliskan "pilih JK-Wiranto, buka usaha, ciptakan lapangan kerja, Indonesia sejahtera”. 


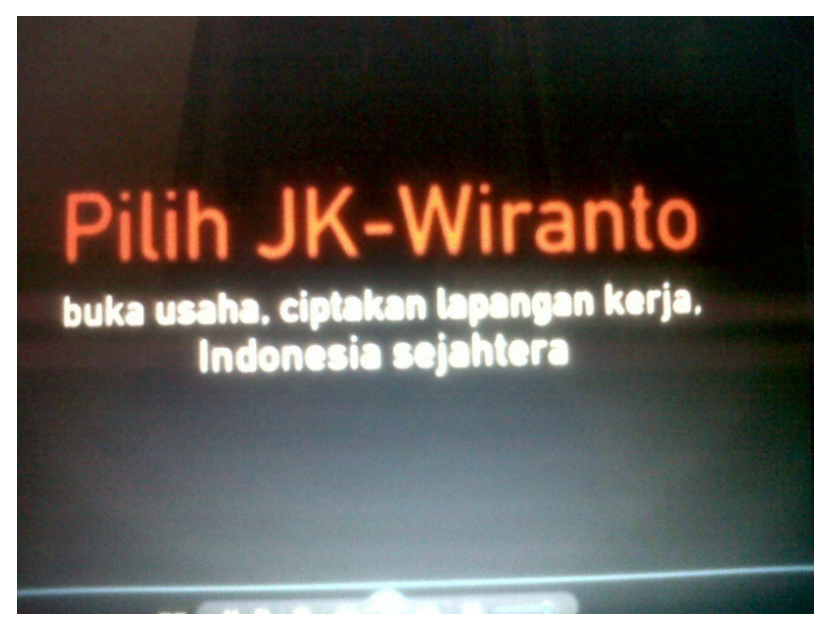

Gambar 10. Visualisasi kalimat penegasan JK dan programnya.

Disini JK ingin memberi sebuah harapan dengan digulirkannya program "mampu" tersebut. Harapannya Indonesia bisa sejahtera dengan mengembangkan banyak wirausahawan muda dan membuka lapangan pekerjaan baru. Dan kata "mampu" dijadikan JK sebagai penyemangat para pemuda, JK yakin jika para pemuda juga mampu. Mampu untuk menjadi tulang punggung negara.

Iklan ini bila dicermati sebenarnya bisa menjadi boomerang buat JK sendiri. Karena selama masa 2004-2009 JK adalah wakil presiden, maka kurang tepat jika iklan tentang penganguran, kemiskinan masih juga ditampilkan. Akan muncul pertanyaan di masyarakat, selama ini sebagai wakil presiden apa saja yang pernah dilakukan, bukankan wakil presiden adalam pemangku kebijakan. Walaupun apologi bisa dimunculkan dengan mengatakan kalau wakil presiden tidak mengambil kebijakan sepenuhnya, karena masih ada diatasnya yaitu presiden.

\section{SIMPULAN}

Asumsi awal, iklan terdiri dari berbagai rangkaian gambar dan juga vois over yang mengkonstruksi sebuah alur untuk menciptakan dan mengkonstruksi sosok dengan citra tertentu. Dari pembahasaan diatas dapat diambil kesimpulan terdapat hiperrealitas sosok negarawan dan mitos tentang kemiskinan.

Pasangan JK-Wirantoyang melambaikan tangan dengan latar belakang tugu proklamasi. Tentu hal ini dimaksudkan untuk menunjukan semangat proklamasi yang dilakukan oleh Soekarno dan Hatta beberapa dekade lalu.

Jika muncul kata proklamasi, maka asosiasi akan langsung tertuju pada sosok sang proklamator. Dan proklamator adalah sosok negarawan. Di sinilah posisi hiperrealitas negarawan diambil dan menjadi tekanan dalam iklan pasangan ini. Namun, sebenarnya jika dicermati tidak semua orang yang berada di Tugu Proklamasi dapat diidentikan dengan sang proklamator itu sendiri atau lebih jelasnya setiap orang yang berada di tugu proklamasi adalah negarawan. Tentu tidak salah mengatakan bahwa ada seorang negarawan yang menggunakan pakaian tertentu, berbicara dengan gaya orasi tertentu. Namun itu tidak sepenuhnya benar. Karena ukuran negarawan seseorang tidak ditentukan oleh cara dia berpakaian, berbicara maupun bentuk fisiknya.

Dalam pandangan JK-Wiranto, sebagaimana termuat dalam iklan di atas orang miskin adalah para penganguran, pemuda yang bergadang siang hari, masyarakat yang nongkrong di warung. Kemudian sebaliknya, kesejahteraan di visualisasikan dengan pembangunan gedung pencakar langit, sawah yang hijau, pasar yang ramai. Akan tetapi itu semua tidak bisa dijadikan sebagai sebuah ukuran. Di sinilah penekanan mitos kemiskinan dimunculkan dalam iklan ini.

Keberadaan orang kecil atau tokoh politik sering menamai dengan wong cilik dalam bahasa Jawa, cukup familiar pula di agenda dan kegiatan politik. Termasuk didalam iklan. Orang kecil atau masyarakat bawah dikonotasikan sebagai masyarakat yang hidup di pinggiran desa, berpenghasilan rendah, tidak berpendidikan dan juga tidak memiliki pangkat maupun jabatan apapun. Keberadaan mereka sering dijadikan sebagai komoditas mencari simpati dan mendongkrak elektabilitas elit politik. 


\section{DAFTAR PUSTAKA}

Barthes, Roland. 2012. Elemen-elemen Semiologi. Terj. M. Ardhiyansyah. Yogyakarta: IRCiSoD

Roland. 1981. Mithologies. New York: Granada Publising.

Darmawan, HBC. 2004. Sang Kandidat; Analisis Psikologi Politik Lima Kandidat Presiden dan Wakil Presiden RI Pemilu 2004. Jakarta: Kompas

Eriyanto. 2011. Analisis Isi; Pengantar MetodologiuntukPenelitianKomunikasi dan Ilmu-Ilmu Sosisl lainnya. Jakarta; Kencana.

Hasanuddin. 1998. Pengaruh Mitos dalam Karya Sastra Indonesia Warna Lokal Minagkabau. Dalam Majalah Humanus. Lemlit IKIP Padang.

Hartoko, Dicki dan B. Rahmanto. 1986. Pemandu di Dunia Sastra. Yogyaarta: Kanisius

Jorgensen, Marianne W. dan Louise J. Philips. 2007. Analisis Wacana: Teori dan Metode. Yogyakarta: Pustaka Pelajar.

Junus, Umar. 1986. Mitos dan Komunikasi. Jakarta: Gramedia.

Piliang, Yasraf Amir. 2012. Semiotika dan Hipersemiotika; Kode, Gaya dan Matinya Makna. Bandung: Matahari.

Dinamika Politik di dalam Era Virtualitas. Yogyakarta: Jalasutra

Sobur, Alex. 2004. Semiotika Komunikasi. Bandung: Remaja Rosdakarya

Storey, John. 2004. Teori Budaya dan Budaya Pop, Memetakan Lanskap Konseptual Cultural Studies. Yogyakarta: Qalam.

Sunardi, St. 2007. Semiotika Negativa. Yogyakarta: Kanal.

\section{Internet}

h t t p : / / p e m il u. o k e z o n e.com / $\mathrm{read} / 2009 / 06 / 24 / 268 / 232551 /$ seringklaim-keberhasilan-sinyal-jk-otoriter. diakses 17 November 2013.

h t t p : / / p e m il u . okezon e.com / $\mathrm{read} / 2009 / 06 / 02 / 268 / 225309 /$ sederettokoh-menjadi-tim-kampanye-jkwiranto. Diakses 9 September 2014.

http://news.detik.com/read/20o9/o6/10/o6 450o/1145204/70o/ini-dia-tim-suksesjk-wiranto. Diakses 9 September 2014

Kompas 2 Juni 2009. 
